\title{
Beneficial role of quinoa and Nigella sativa seeds as antihyperuricemia in rats
}

\author{
El-Kewawy $\mathrm{HE}^{1}$ and Morsy GM ${ }^{2}$
}

1) Nutrition and Food Science; Home Economics dep.; Faculty of Specific Education; Mansoura University

2) Department of biochemistry and Nutrition - faculty of women for Arts, Science and Education -Ain Shams university

\section{ABSTRACT}

7 his research targeted to evaluate the effect of Quinoa seed (QS); Nigella sativa seeds (NSS) and their combination on hyperuricemia. Thirty male $\mathcal{L}$ albino rats assigned to five groups $(n=6)$. The first these fed on the standard diet as normal control rats. The other rats $(n=24)$, received a basal diet including a $20 \mathrm{~g} / \mathrm{kg}$ diet potassium oxonate to create hyperuricemia. Then ill rats divided into four groups. The hyperuricemic control group and three groups treated with added to their diet 10\% QS; 4\% NSS and mix from $10 \%$ QS plus $4 \%$ NSS respectively. After that, the researcher calculated the biological status and estimated biochemical analysis. The results appear that high uric acid groups, in which feeding remedy diets showed no significant variation in biological parameters compared with the normal rats. The same groups indicated a significant improvement in renal function when compared with the injury group. Likewise, rising kidney tissues antioxidant status "superoxide dismutase; catalase and glutathione transferase" and decrease "malondialdehyde and interleukin-1 (IL-6)". Also, the mixture diet increased antioxidant activity. This study concluded that QS and NSS may improve kidney function and may reduce oxidative stress. This article recommended that special meals of hyperuricemic patients supplemented by a blend of QS and NSS.

Key words: quinoa seed, Nigella sativa seed, Hyperuricemia 


\section{INTRUDUCTION}

Hyperuricemia is one of the evident spread of metabolic diseases in populations. It is famous for the rise of uric acid levels in the blood (Chen et al., 2009). This phenomenon may give an increase to problems, like gout (pilling up of uric acid crystals in the joints, especially in toes or fingers) and renal stones or kidney failure (Kaneko et al., 2014). Uric acid is the finished output of purine metabolism. Purines synthesized within the cells of the body. Also, it obtained from foods, which compounds containing nitrogen. Purines perhaps accumulate in tissues, forming crystals. These crystals lead to severe inflammation and cause tissue damage known through articular cartilage ulceration osteophytes and erosive lesions (Corrado et al., 2006).

Some cereals play a primary role in new lifestyles; to face consumer requests due to their physiological and metabolic advantage. Grain consuming has outspread from the breakfast list to any time of the day. These products have become an excellent way to insert functional food into the diet of consumers. Quinoa seed (QS) contains high biologically valuable "proteins, low glycemic index carbohydrates, phytoestrogens, and omega-3 and 6 fatty acids" that are beneficial to human health (Farinazzi-Machado et al., 2012 and Ruini et al., 2015). It has notable nutritional distinctive characteristics; not only from its protein content $(15 \%)$ but also of its significant balance in amino acids (Abugoch, 2009) with the highest percentage of lysine $(5.1 \%-6.4 \%)$ and methionine $(0.4 \%-1.0 \%) \quad$ contents (Jacobsen, 2003 and Jancurova et al., 2009). Some researchers have suggested that QS may increase the secretion of immune substances called cytokines, which can be beneficial for both preventing and treating inflammation (Yao et al., 2014).

Nigella Sativaseed (NSS) is a very rich antioxidants source 
ells influences many biological activities (Rahmani and Aly 2015). Thymoquinone is the main active ingredient of NSS; as an antioxidantitem and has anti-inflammatory properties (Mahmoud et al., 2019). NSS had numerous biological actions like many anti-cancer, antiinflammatory, cardiovascular, renal, immunomodulatory, and anti-diabetic properties. Also, it acts as an antimicrobial, parasitic, and an antihypertensive. Besides its widespread use for the treatment of many diseases such as bronchitis, diarrhea, rheumatism and skin disorders (Bamosa, 2015).

The current research is a trial for evaluation of effective role of QSand NSSto mitigation hyperuricemia in experimental rats.

\section{MATERIALS \& METHODS}

\section{Materials:}

The experimental seeds (QS and NSS) brought from the agricultural research center, Giza, Egypt. Quinoa seeds were washed for 20 minutes with tap water to eliminate toxic saponins and then dried at $45^{\circ} \mathrm{C}$ for 12 hours. These seeds were grinded in an electric blender into a fine powder, then packed in plastic bags and stored in the deep freezer until used for diet supplementation.

\section{Chemicals:}

Potassium oxonate gotten from El-Gomhorya Company, Cairo Egypt,Kits utilized for biochemical analyses fetched from Gamma Trade Company,Cairo Egypt.

\section{Animals:}

Thirty male albino rats of Sprague Dawley strain purchased from "Laboratory Animal Colonies, Pharmacology Department Faculty of Medicine, and Mansoura University"; the average weight was $120 \pm 10 \mathrm{~g}$. Animals fed a standard/basal diet and water ready as needed. The rats left for 7 days to adapt according to (Guidelines for ethical conduct in the care and use of animals in research obtained from the 
concerned department in Mansoura University).

\section{Standard Diet:}

Basal diet was prepared based on AIN 1993 (Reeves et al. 1993).

\section{Methods:}

\section{Chemical analysis:}

The gross constituents of seeds as moisture, protein, fats and ash were estimated in accordance with (A.O.A.C. 2005) whereas carbohydrates were calculated by deduction. Minerals content including zinc $(\mathrm{Zn})$, iron $(\mathrm{Fe})$, sodium $(\mathrm{Na})$, manganese (Mn), magnesium $(\mathrm{Mg}), \quad$ cupper $(\mathrm{Cu}) \quad$ and calcium $(\mathrm{Ca})$ were determined according to (Chapman \& Pratt, 1978)

\section{The experimental design:}

After acclimation on a basal diet for seven days rats classified into two groups. The first $(n=6)$ left as the normal control group, fed on standard diet. The second group $(n=24)$ rats were fed on basal diet contains $20 \mathrm{~g} / \mathrm{kg}$ diet potassium oxonate for 42 days to induce hyperuricemia as pointed by Mazzali et al., (2001). The uric acid level was measured for all rats at begin experiment and after six weeks of taking potassium oxonate to confirm the occurrence of hyperuricemia. A high uric acid was found in all rats that took potassium oxonate. Hyperuricemic rats classified into 4 groups as following: Hyperuricemic as a positive control group fed on a standard diet and water adlibitium. Quinoa seeds group: received a basal diet containing $10 \%$ QS according to (Ruales et al., 2002) with an adjustment in the method by half the dose and double the duration. Nigella sativa group: intake on basal diet and 4\% NSS. Mixed seeds group: fed on a basal diet containing $10 \%$ QS with $4 \%$ NSS according to EL-Bahay et al., (2007).

\section{Biological items:}

Daily feed intake (FI), protein intake (PI) and weekly body weight gain (BWG) werecalculated. Feed efficiency 
ratio (FER) and protein efficiency ratio (PER) were specified according to the method of (Chapman et al., 1959).

At the ending of the trial term (35days), all rats were fastedovernight before sacrificing. Blood samples were taken from hepatic portal vein, one part was used for different determination and the rest blood was left in a centrifuge tube at room temperature for $15 \mathrm{~min}$ and then centrifuged at 4000 rpm for 10 min to obtain serum. Serum was separated in plastic vials and stored at $-20 \mathrm{C}$ until analysis. Then, kidney were taken and homogenized in super cold $0.1 \mathrm{M}$ phosphate buffer at $\mathrm{pH} \quad 8.0 \quad(1: \quad 4 \quad \mathrm{w} / \mathrm{v})$ using a homogenizer. Homogenate kidney was centrifuged at 4000 rpm for $15 \mathrm{~min}$ and supernatants were gathered to estimate antioxidants enzyme.

\section{Biochemical analysis:}

Determination of kidneys function "creatinine, urea and uric acid" were done according to Bonsens and Taussky(1984), Patton and Crouch(1977) and Fossati et al., (1980).Total protein, albumin and globulin were determination as described by method of Weichse lbauml (1946), Bartholomev and Delany (1966) and Coles (1974) respectively. An antioxidant enzyme in kidney tissue such as "Superoxide dismutase (SOD); glutathione peroxidase (GPXs); glutathione transferase (GST) and catalase (CAT)"estimatedas the method mentioned by Beuchamp and Fridovich (1971); Tapple (1978); Moran et al., (1979) and Cohen et al.,(1970). But, malondialdehyde determined according to Uchiyama and Mihara, (1978). Hemoglobin and packed cell volume were determined according to Drabkin, (1949) and McInory (1954). Whilst, immunoglobulin $\mathrm{G}$ and $\mathrm{M}$ ( $\mathrm{IgG}$ and $\operatorname{IgM}$ ) were determined by direct ELISA according to Manohars and Selvakumaran, (2012). Interleukin-6 (IL-6); IL-6 levels in kidney tissue homogenate was determined by using Rat IL-6 Immunoassay kit 
from R\&D Systems Inc. (USA) be of the same mind with Hibi et al.,(1996).

\section{Statistical analysis:}

Data were analyzed using analysis variance "ANOVA" test; (LSD) at $\mathrm{P} \leq 0.05$ and Duncan's test as the methods described by Gomez and Gomez, (1984).

\section{RESULTS \& DISCUSSION}

The chemical composition of QS and NSS explained in table "1". The major constituents of QS and NSS indicated that fat, protein and ash for NSS were higher than QS. Moisture and carbohydrates were the lowest in NSS. The results of the elementary chemical composition of QS were conformable with those stated by Halaby et al., (2017) whose demonstrated that moisture, fat, protein, ash and total carbohydrates were as follows: $9.5 ; 6.9 ; 14.2 ; 3.2$ and 63.5 $\mathrm{g} / 100 \mathrm{~g}$. Whiles, the results of the chemical components of the NSS were in line with Atta,
2003 as follows; moisture, ash, oil, proteins, and total carbohydrates contents in the range of $3.8-7.0 \%, 3.7-4.7 \%$, 22.0 to $40.35 \%, 20.85-31.2 \%$, and $24.9-40.0 \%$, respectively.

Data in Table

illustrated some minerals content of QS and NSS. The valueof minerals content NSS were displayed in table 2 lower than it's in QS. These results are congruent, with those acquired by Atta, (2003); Nickavar et al., (2003); Ashraf et al., (2006) and Halaby et al., (2017).

The findings in the third table indicated that the hyperuricemic rats recorded significantly lower results in BWG, FER, and PER than the healthy rats. PI and FI consequences have no significant differences in the positive control group, the negative control group, and all treated groups. The improvement of ill animals fed QS; NSS and mixture them showed significantly higher in BWG, FER, and PER value than a high uric acid group. These outcomes were maybe because 
of the more content nutritional values of QS like zinc, magnesium, copper, iron, and calcium (showed in Table 2). Furthermore, potassium, magnesium, and calcium are present in it with bioavailable forms, and therefore their contents are sufficient for a balanced diet (Vega-Galvez, et al., 2010). QS is also a rich source of flavonoids that improves the biological functions of their antioxidant properties. These inferences are in harmony with those obtained by Ruales et al. (2002). The improvement of biological sings in rats groups that consumed NSS was due to its nutrient content and thymoquinone substance (Takruri and Dameh, 1998). This study revealed that the best biological parameters were in the group that consumed a blend of QS with NSS.

The datum in Table (4) explained that the hyperuricemic control group noted significantly high results in uric acid, urea, and creatinine in comparison to normal rats. While animals fed three remedy diets showed a significant reduction in renal function in differential to an injury control group. The best improvement was for the group that consumed a mixture of QS with NSS, followed by NSS only then QS. Rising uric acid value in serum could stimulus risk, like renal failure or kidney stones and gout (Wang et al., 2015). The data was in line with Halaby et al., (2017) they concluded that diet fortified QS can improving in the serum uric acid, urea, and creatinine levels. The results of improvement in kidney function may be attributed to thymoquinone that is the main active compound found in NSS. It has a probable capacity to preserve kidney action, rein the formation of urinary stones, lower retention crystals in the kidney tissue and spur their excretion in urine (Benhelima et al., 2016).

QS or NSS contain some important compounds that help improve renal health as phenolic compounds, flavonoids, minerals, and vitamins. Dietary flavonoids diminish uric acid 
levels and keep a safe kidney from damage, the mechanism underlying this effect is probably, due to their molecular structure, these natural antioxidants act as direct superoxide scavengers and xanthine oxidase (XO) inhibitors, resulting in the suppression of Reactive Oxygen Species (ROS) and uric acid formation (Lin et al., 2015).

Table (5) recorded that hyperuricemic rats had significantly lower values of total protein (TP), albumin, and globulin than normal rats. Suffering hyperuricemic rats, which fed on a treated diet with QS or NSS and a mixture of both showed non-significant variation in $\mathrm{TP}$, albumin, and globulin in comparison with normal rats. However, noted these groups a significant increase compared with the hyperuricemic control group. Low blood protein values in rats with elevated uric acid where uric acid is tightly merged to $\alpha 1$ $\alpha 2$ globulin, even though in little amounts (about 0.1-0.2 mg/ dl). The Link of the other protein is loose, allowing glomerular uric acid to be filtered. Prior researches indicate that albumin is an assessment of uric acid value and is confirming in laboratory research suggesting that $1 \mathrm{~g} / \mathrm{dl}$ of albumin shall combine with $0.6 \mathrm{mg} / \mathrm{dl}$ of uric acid (Adams et al., 1984).

The results in table 6 illustrated that the hyperuricemic rats' had significantly lower SOD, CAT, GPXs, and GST value of kidney tissue while MDA was highly significant compared with normal rats. Hyperuricemia rat groups fed on diet Supported with QS or NSS and together it showed a significant increase of SOD, GPXs, GST, and CAT, however a significant reduction MDA in comparison with hyperuricemic control. One of the main defense systems that reduce the occurrence of toxicity caused by cracks in the body are antioxidants QS is a rich source of flavonoids that improve the biological functions of their antioxidant properties (Abderrahim et al., 2015). The balance between antioxidants 
and free radicals is a necessary and effective process in removing oxidative stress in intracellular organelles. The rats treated by QSplus NSS have shown an increase in the activity of these enzymes, demonstrating their effective ability to prevent the harmful effects of free radicals; thymoquinone is amongst the main antioxidant components of NSS.The intake of NSS in all forms develops the antioxidant defense capacity of the body (Ermumcuand Sanlier2017). The present results in table 6 has been confirmed by Pasko et al., (2010) who reported that QS can appear like evenly safeguard agents for rats by diminution the lipid peroxidation in plasma and different tissues and rising the antioxidant capacity. Also, the findings are in agreement with Rahmathulla

(2013) who mentioned that the first line of cellular defense against oxidative harm is scavenger free radical enzymes like superoxide dismutase, glutathione peroxidase, glutathione transferase, and catalase.
Reduced enzymes may be due to enhanced lipid peroxide.

Table 7 data indicated that a significant reduction for the $\mathrm{HB}, \mathrm{PCV}$, IgM, and $\mathrm{IgG}$ values; while the interleukin-1 (IL-6) level was highly significant of the hyperuricemic rats. These signs were due to potassium oxonate that caused the hyperuricemia increased oxidative stress; which has a potential effect on the function of cell $\mathrm{B}$ in vivo as a result of consequently a decrease in $\operatorname{IgM}$ and IgG levels (Ercal, et al., (2000). Groups fed diets with QS / NSS or mix improved IgM and IgG levels due to seeds as an antioxidant and their superior ability to reduce internal oxidative stress. QS and NSS have an anti-inflammation performance to inhibit hyperuricemia from developing into gout and other inflammatory disorders. Gout takes part in many pathogenic with other inflammatory disorders, like a rapid rising in the produce of pro-inflammatory cytokines, including IL-1 $\beta$, IL-6, and TNF- 
$\alpha$ (Terkeltaub, 2006 and Wang et al., 2015).

\section{CONCLUSION}

This study concluded that the results showed that the mixture of QS with NSS improving kidney function and may significantly reduce oxidative stress and boost the antioxidant defense case.

\section{RECOMMENDATION}

The research recommended the need to supplement special meals for hyperuricemic patients and humans suffering oxidative stress by a mix of QS and NSS powder.

\section{REFERENCES}

\section{AOAC (2005):}

Official methods for analysis of the association of official analytical chemist. A. O.A.C., 12th $E d$. Washington, $D$.

\section{Abderrahim F; Huanatico E;} Segura R; Arribas S; Gonzalez

\section{MC and Condezo-Hoyos L} (2015):

Physical features, phenolic compounds, betalains and total antioxidant capacity of coloured quinoa seeds (Chenopodium quinoa Willd.) from Peruvian Altiplano. Food Chem 2015, 183: 83-90.

Abugoch JLE (2009):

"Quinoa (Chenopodium quinoa Willd): composition, chemistry, nutritional, and functional properties". Advances in Food and Nutrition Research vol.58: 1-31.

\section{Adams WH; Harper JA;} Heotis PM and Jamner AH (1984):

Hyperuricemia in the inhabitants of the Marshall Islands. Arthritis and Rheum. 27(6): 713-716.

Ashraf M; Ali Q and Iqbal Z (2006): 
El-Kewawy $\mathrm{HE}^{I}$ and Morsy $\mathrm{GM}^{2}$

Effect of nitrogen application rate on the content and composition of oil, essential oil and minerals in black cumin (Nigella sativa L.) seeds. J. Sci. Food Agric., 86: 871-876.

Atta MB (2003):

Some characteristics of nigella (Nigella sativa L.) seed cultivated in Egypt and its lipid profile. Food Chem., 83: 63-68.

Badary O; Abdel-Naeem A; Abdel-Wahab $M$ and Hamada F (2001):

The influence of thymoquinone on doxorubicin- induced hyperlipidemic nephropathy in rats. Toxicol. 143: 219-226.

Bamosa A (2015):

"A review on the hypoglycemic effect of Nigella sativa and thymoquinone," Saudi Journal of Medicine
\&Medical Sciences, vol.3, no.1, pp.2-7, 2015

Bartholomev RJ and Delany A (1966):

Proc Aust. Assoc.

Biochemists.1, 214.

Benhelima A; Kaid-Omar Z; Hemida H; Benmahdi $T$ and Addou A (2016):

Nephroprotective and diuretic effect of Nigella sativa L seeds oil on lithiasicwistar rats. African Journal of Traditional,

Complementary and Alternative

Medicines.;13(6):204-14.

Beuchamp C and Fridovich J (1971):

Superoxide

dismutase.Improved an assay applicable to acrylamide gels. Anal Biochem.44:276-287.

Bonsens K E and Taussky D H (1984): 
Determination of serum creatinine .J ChemInv, 27: $648-660$.

Chapman DG; Gastilla $R$ and Campbell TA (1959):

Evaluation of protein in food. I. A. Method for the determination of protein efficiency ratio. Can. J. Biochem. Physio. I (37) 679-686.

Chapman $H$ and Pratt $P$ (1978):

Methods of analysis from soils, plant and water.Univ. of California. Div. Agric. Sci., pp: 50.

\section{Chen JH; Chuang SY; Chen} HJ; Yeh WT and Pan WH (2009):

Serum uric acid level as an independent risk factor for all-cause, cardiovascular, and ischemic stroke mortality: a Chinese cohort study. Arthrit Care Res . 61: 225- 232
Cohen G; Dembuic D and Marcus J (1970):

Measurement of catalase activity in tissue extract. Anal.Biochem., 34, 3038.

\section{Coles EH (1974):}

Liver Function: In Veterinary Clinical Pathology, 2nd Ed. W.B. Saunders Company. Philadelphia: 202-215.

Corrado A; D'Onofrio F; Santoro N; Melillo $N$ and Cantore FP (2006):

Pathogenesis, clinical findings and management of acute and chronic gout. Minerva Med. 97:495-509.

\section{Drabkin D (1949):}

Standardization of hemoglobin measurements. Am. J. Med. Sci., 217-710.

ELBahay AM; AbdEIMagied AA; HalabyMS; Awad R and EL-Said H(2007): 
Protective Influence of Nigella sativa seeds and Honeybee on Chronic Renal Failure in Albino Rats. Egyptian J. of Nutrition NO.4:25-62.

\section{Ercal N; Neal R; Treeratphan} P; Lutz PM; Hammond TC Dennery PA and Spitz DR (2000):

A Role for Oxidative Stress in Suppressing Serum Immunoglobulin Levels in Lead-Exposed Fisher 344 Rats, Arch. Environ. Contam. Toxicol. 39(2), 251-256.

Ermumcu MŞK and Fardet SN (2017):

Black Cumin (Nigella Sativa) and Its Active Component of

Thymoquinone: Effects on Health, Journal of Food and Health Science, 3(4): 170-183 .

Fardet A (2010):

New hypotheses for the health-protective mechanisms of whole- grain cereals: what is beyond fibre? Nutr Res Rev 23: 65-134.

Farinazzi-Machado FM; Barbalho SM; Oshiiwa M; Goulart $R$ and Junior OP (2012):

Use of cereal bars with quinoa (Chenopodium quinoa W.) to reduce risk factors related to cardiovascular diseases. Ciênc.Tecnol.Aliment., Campinas, 32(2): 239244.

Fossati P; Prencipe $L$ and Berti G (1980):

Use of 3, 5 dichloro-2hydroxybenzene sulfonic acid /4-aminophenazon chromogenic system in direct enzymatic assay of uric acid in serum and urine. Clin. Chem., 26: 227-231.

Gomez KA and Gomez AA (1984):

"Statistical Procedures for Agricultural Research". John Wiley 
and Sons, Inc., New York.pp:680.

Halaby MS; Abdel-Rahman M $K$ and Hassan RA (2017):

Protective Influence of

Quinoa on

Hypercholesterolemia in male rats. Curr. Sci. Int., 6(1): 259-270.

Hibi M; Nakajima $K$ and Hirano T (1996):

"IL-6cytokinefamilyand signal Transduction: a model of the cytokine system," Journal of Molecular Medicine, vol.74, no.1, pp.1-12

Jacobsen SE (2003):

"The worldwide potential for quinoa (Chenopodium quinoa Willd.)". Food Reviews International 19.1-2: 167-177.

Jancurova M; Minarovičova $L$ and Dandar A (2009):

"Quinoa - a review". Czech Journal of Food Sciences 27: 71-79.
Kaneko, K., Aoyagi, Y. ; Fukuuchi, T. ;Inazawa, K. and Yamaoka, N. (2014):

Total purine and purine base content of common food stuffs for facilitating nutritional therapy for gout and hyperuricemia. Biol. Pharm. Bull. 37:709721.

Kim IY; Han KD; Kim DH; Eun Y; Cha HS; Koh EM; Lee $J$ and Kim H (2019):

Women with Metabolic Syndrome and General Obesity Are at a Higher Risk for Significant Hyperuricemia

Compared to Men. J. Clin. Med. 8, 837:1-14.

\section{Lin S; Zhang G; Liao Y; Pan} J; Gong D (2015):

Dietary Flavonoids as Xanthine Oxidase Inhibitors: StructureAffinity and StructureActivity Relationships. $J$. Agric. Food Chem. 63, 7784-7794. 
Mahmoud ES; Al-Zahraa F; Al-Shahed N; Ouda EA and Al Anany M G (2019):

Effect of thymoquinone on the structure of the cerebral cortex of adult male albino rats treated with tramadol. The Scientific Journal of AlAzhar Medical Faculty, Girls, (3): 1, 97-110.

Manohars

and

Selvakumaran R (2012):

Estimation of serum immunoglobulin E (IgE) level in allergic asthma and allergic rhinitis patients before and after treatment. Euro. J. Experiment Biol. 2: 2199-2205.

\section{Mazzali M; Hughes J; Kim Y}

G; Jefferson JA; Kang H; Lan HY; Kivlighn S and Johnson R J (2001):

Elevated uric acid increases blood pressure in the rat by a novel crystal independent mechanism. Hypertensio n; 38: 1101-1106.
Mc Inory RA (1954):

Amicro hematocrit for determining the packed cell and hemoglobin concentration on capillary blood. J. Clin Path., 7; 32.

Moran MS; Difierre JW and Manneruik B (1979):

Levels of glutathione reductase glutathione-stransferase in rat lung and liver. Biochim Biophys Acta., 582:6778.

Navruz-Varli S and Sanlier N (2016):

Nutritional and health benefits of quinoa (Chenopodium quinoa Willd.). J. Cereal Sci., 69, 371.

Nickavar B; Mojab F; Javidnia $K$ and Roodgar Amoli MA ( 2003):

Chemical composition of the fixed and volatile oils of Nigella sativa L. Zeitschrift. Fur. Natur for schung., 58: 629-631. 
Pasko P; Bartoń H; Zagrodzki P; Gorinstein S; Folta $M$ and Zachwieja Z (2009):

Anthocyanins, total polyphenols and antioxidant activity in amaranth and quinoa seeds and sprouts during their growth. Food Chem 115:994-998.

Pasko P; Barton H; Zagrodzki P; Izewska A; Krosniak M; Gawlik M; Gawlik M and Gorinstein S (2010):

Effect of diet supplemented with quinoa seeds on oxidative status in plasma and selected tissues of high fructosefed rats. Plant Foods Hum. Nutr. 65 (2), 146151.

\section{Patton CJ and Crouch SR (1977):}

Enzymatic colorimetric method to determination urea in serum. Anal. Chem., 49: 464.
Rahmani AH and Aly SM (2015):

Nigella Sativa and Its Active Constituents Thymoquinone Shows Pivotal Role In The Diseases Prevention And Treatment . Asian $J$ Pharm Clin Res, Vol 8, Issue 1, 2015, 48-53.

\section{Rahmathulla SBM (2013):}

Effect

of

Tribulusterrestris fruit aqueous extract on hyperlipidemia and maintenance of liver architecture in isoproterenol-induced myocrdial infarction in rats. Int. J. Pharm. Bio. Sci.4: 983 - 992 .

Reeves PG; Nielsen FH and Fahmy GG (1993):

AIN-93.Purified diets for laboratory rodents: Final report of the American Institute of Nutrition adhocwriling committee on the reformulation of the AIN-76 A Rodent 
diet. J. Nutrition, 123: 1939-151.

Ruales J; De Grijalva Y; Lopez-Jaramillo $P$ and Nair BM (2002):

The nutritional quality of infant food from quinoa and its effect on the plasma level of insulin-like growth factor-1 (IGF-1) in undernourished children. Int $J$ Food Sci Nutr 53:143-54.

Ruini L; Ciati R; Pratesi C; Marino $M$ and Principato $L$ (2015):

Working toward healthy and sustainable diets: the "Double Pyramid Model" developed by the Barilla center for Food and Nutrition to raise awareness about the environmental and nutritional impact of foods. Frontiers in Nutrition, 2: 1-6.

Takruri HM and Dameh MA (1998):
Study of the nutritional value of black cumin seeds (Nigella sativa L.). J Sci of Food Agri 76:404-6.

Tapple AL (1978):

In Glutathione peroxidase and hydroperoxidase methods, in Methods in Enzymology, Vol II. Sidney F., Lester P., editors. Academic Press; New York: 506-513

Terkeltaub R (2006);

Gout in 2006: The perfect storm, Bull NYU Hosp Jt Dis; 64:82-86.

Uchiyama $M$ and Mihara $M$ (1978):

Determination of malondialdhyde precursor in tissues by thiobarbituric acid test.Anal. Biochem.,86 (1),271-278.

Vega-Galvez A; Miranda M; Vergara $\mathrm{J}$; Uribe $\mathbf{E}$ and Puente L (2010): 
El-Kewawy $\mathrm{HE}^{1}$ and Morsy $\mathrm{GM}^{2}$

Nutrition facts and functional potential of quinoa (Chenopodium quinoa Willd.), an ancient Andean grain: a review. J Sci Food Agric, 90: 2541-2547.

\section{Wang MX; Liu YL; Yang Y;} Zhang DM; Kong LD (2015):

Nuciferine restores potassium oxonateinduced hyperuricemia and kidney inflammation in mice. Eur $J$ Pharmacol; 747:59-70.

\section{Weichselbaum TF (1946):}

An accurate and rapid method for the determination of protein in small amount of blood serum and plasma $. A m . J$ .Clin Path, (16):40.

Yaman I and Balikci E (2010): Protective effects of Nigella sativa against gentamicin-induced nephrotoxicity in rats. Exp Toxicol Pathol; 62(2):183-90.

Yao Y; Yang X; Shi Z and Ren G (2014):

Anti-inflammatory activity of saponins from quinoa (Chenopodium quinoa Willd.) seeds in lipopolysaccharide-

stimulated RAW 264.7 macrophages cells. $J$ Food Sci. 2014 May; 79(5):H1018-23. 
Table (1): Elementary Chemical composition of quinoa and Nigella sativa seeds -dry weight- (g/100g):

\begin{tabular}{|l|c|l|l|l|l|}
\hline \multirow{2}{*}{$\begin{array}{c}\text { Variables } \\
\text { Sample }\end{array}$} & Moisture & \multicolumn{5}{|c|}{ Ash } & Fat & Protein \% & Carbohydrates \\
\cline { 2 - 6 } & \multicolumn{5}{|c|}{$\%$} \\
\hline QS & 9.62 & 3.35 & 7.25 & 15.85 & 63.93 \\
\hline NSS & 5.95 & 4.31 & 34.6 & 20.2 & 34.94 \\
\hline
\end{tabular}

Table (2): Some minerals content of quinoa and Nigella sativa seeds dry weight- (mg/100g):

\begin{tabular}{|l|c|c|c|c|c|c|c|c|c|}
\hline \multirow{2}{*}{$\begin{array}{c}\text { Content } \\
\text { Sample }\end{array}$} & Zn & Fe & K & Na & Mn & Mg & Cu & Ca \\
\cline { 2 - 9 } & \multicolumn{7}{|c|}{$\mathbf{m g} / \mathbf{1 0 0 g}$} \\
\hline QS & 42.26 & 67.84 & 884.97 & 42.91 & 31.11 & 2533.66 & 17.12 & $\mathbf{1 0 4 1 . 6 6}$ \\
\hline NSS & 6.43 & 9.1 & 812.32 & 19.41 & 8.44 & 270.87 & 2.57 & $\mathbf{5 9 0 . 7 6}$ \\
\hline
\end{tabular}


Table (3): Effect of quinoa and Nigella sativa seeds on biological parameters of rats suffering from hyperuricemia

\begin{tabular}{|c|c|c|c|c|c|}
\hline $\begin{array}{c}\text { Parameters } \\
\text { Groups }\end{array}$ & $\mathrm{BWG}(\mathrm{g})$ & $\mathrm{PI}(\mathrm{g} / \mathrm{d})$ & $\mathrm{FI}(\mathrm{g} / \mathrm{d})$ & FER & PER \\
\hline $\begin{array}{c}\text { Normal } \\
\text { control group }\end{array}$ & $40.86 \pm 4.38^{\mathrm{a}}$ & $3.01 \pm 0.12^{\mathrm{a}}$ & $15.04 \pm 0.56^{\mathrm{ab}}$ & $0.078 \pm 0.008^{\mathrm{a}}$ & $0.388 \pm 0.037^{\mathrm{a}}$ \\
\hline $\begin{array}{c}\text { Hyperuricemia } \\
\text { control group }\end{array}$ & $27.03 \pm 2.31^{\mathrm{c}}$ & $3.04 \pm 0.11^{\mathrm{a}}$ & $14.59 \pm 0.56^{\mathrm{b}}$ & $0.053 \pm 0.004^{\mathrm{c}}$ & $0.255 \pm 0.027^{\mathrm{c}}$ \\
\hline $\mathbf{Q S}$ & $33.96 \pm 1.05^{\mathrm{b}}$ & $3.00 \pm 0.14^{\mathrm{a}}$ & $14.62 \pm 0.39^{\mathrm{b}}$ & $0.066 \pm 0.002^{\mathrm{b}}$ & $0.324 \pm 0.020^{\mathrm{b}}$ \\
\hline $\boldsymbol{N S S}$ & $38.20 \pm 1.64^{\mathrm{a}}$ & $3.06 \pm 0.12^{\mathrm{a}}$ & $15.17 \pm 0.62^{\mathrm{ab}}$ & $0.072 \pm 0.002^{\mathrm{ab}}$ & $0.356 \pm 0.015^{\mathrm{a}}$ \\
\hline $\mathbf{Q S}+\boldsymbol{N S S}$ & $40.32 \pm 1.63^{\mathrm{a}}$ & $3.11 \pm 0.06^{\mathrm{a}}$ & $15.40 \pm 0.54^{\mathrm{a}}$ & $0.075 \pm 0.005^{\mathrm{a}}$ & $0.371 \pm 0.015^{\mathrm{a}}$ \\
\hline
\end{tabular}

Average values in every column holding unlike superscript $(a, b, c)$ noted significant variation. Means with the same letter are insignificantly different. QS=Quinoa seed NSS= Nigella sativa seed.

Table (4): Effect of quinoa and Nigella sativa seeds on kidney function of rats suffering fromhyperuricemia

\begin{tabular}{|c|c|c|c|}
\hline \multirow{2}{*}{$\begin{array}{c}\text { Parameters } \\
\text { Groups }\end{array}$} & Urea & Uric acid & Creatinine \\
\cline { 2 - 4 } & \multicolumn{3}{|c|}{$\mathbf{~ m g / d l}$} \\
\hline $\begin{array}{c}\text { Normal control } \\
\text { oroun }\end{array}$ & $35.02 \pm 2.61^{\mathrm{d}}$ & $3.28 \pm 0.46^{\mathrm{c}}$ & $0.69 \pm 0.027^{\mathrm{d}}$ \\
\hline $\begin{array}{c}\text { Hyperuricemia } \\
\text { control group }\end{array}$ & $71.63 \pm 5.64^{\mathrm{a}}$ & $8.37 \pm 1.49^{\mathrm{a}}$ & $1.74 \pm 0.034^{\mathrm{a}}$ \\
\hline $\mathbf{Q S}$ & $47.99 \pm 4.23^{\mathrm{b}}$ & $5.18 \pm 0.68^{\mathrm{b}}$ & $0.87 \pm 0.029^{\mathrm{b}}$ \\
\hline $\boldsymbol{N S S}$ & $43.54 \pm 3.93^{\mathrm{bc}}$ & $4.22 \pm 0.14^{\mathrm{bc}}$ & $0.75 \pm 0.030^{\mathrm{c}}$ \\
\hline $\mathbf{Q S}+\boldsymbol{N S S}$ & $39.75 \pm 1.55^{\mathrm{cd}}$ & $3.61 \pm 0.25^{\mathrm{c}}$ & $0.74 \pm 0.048^{\mathrm{cd}}$ \\
\hline
\end{tabular}

Average values in every column holding unlike superscript $(a, b, c)$ noted significant variation. Means with the same letter are insignificantly different. QS =Quinoa seed NSS= Nigella sativa seed. 
Table (5): Effect of quinoa and Nigella sativa seeds on total protein (T.P), albumin and globulin of rats suffering from hyperuricemia

\begin{tabular}{|c|c|c|c|}
\hline \multirow{2}{*}{$\begin{array}{c}\text { Parameters } \\
\text { Groups }\end{array}$} & TP & Albumin & Globulin \\
\cline { 2 - 4 } & \multicolumn{3}{|c|}{$\mathrm{mg} / \mathrm{dL}$} \\
\hline $\begin{array}{c}\text { Normal control } \\
\text { group }\end{array}$ & $7.98 \pm 0.35^{\mathrm{a}}$ & $3.88 \pm 0.25^{\mathrm{b}}$ & $4.10 \pm 0.17^{\mathrm{a}}$ \\
\hline $\begin{array}{c}\text { Hyperuricemic } \\
\text { control group }\end{array}$ & $5.28 \pm 0.15^{\mathrm{b}}$ & $2.93 \pm 0.06^{\mathrm{c}}$ & $2.35 \pm 0.12^{\mathrm{c}}$ \\
\hline $\mathbf{Q S}$ & $7.77 \pm 0.55^{\mathrm{a}}$ & $3.90 \pm 0.21^{\mathrm{ab}}$ & $4.07 \pm 0.14^{\mathrm{ab}}$ \\
\hline $\boldsymbol{N S S}$ & $7.93 \pm 0.38^{\mathrm{a}}$ & $4.03 \pm 0.13^{\mathrm{ab}}$ & $3.79 \pm 0.27^{\mathrm{ab}}$ \\
\hline $\mathbf{Q S}+\boldsymbol{N S S}$ & $8.01 \pm 0.31^{\mathrm{a}}$ & $3.96 \pm 0.20^{\mathrm{ab}}$ & $4.05 \pm 0.17^{\mathrm{ab}}$ \\
\hline
\end{tabular}

Average values in every column holding unlike superscript $(a, b, c)$ noted significant variation. Means with the same letter are insignificantly different. QS=Quinoa seed NSS= Nigella sativa seed $T P=$ total protein

Table (6): Effect of quinoa and Nigella sativa seeds on SOD, GPX, GST, CAT and MDA in kidney of rats suffering from hyperuricemia

\begin{tabular}{|c|c|c|c|c|c|}
\hline \multirow{2}{*}{ Parameters } & SOD & CAT & GPX & GST & MDA \\
\cline { 2 - 6 } & \multicolumn{4}{|c|}{$\boldsymbol{\mu} / \mathbf{m g}$} & $(\mathbf{m m o l} / \mathbf{g})$ \\
\hline $\begin{array}{c}\text { Normal control } \\
\text { group }\end{array}$ & $94.31 \pm 4.96^{\mathrm{b}}$ & $4.47 \pm 0.17^{\mathrm{a}}$ & $94.87 \pm 4.28^{\mathrm{a}}$ & $5.10 \pm 0.19^{\mathrm{a}}$ & $6.55 \pm 0.63^{\mathrm{c}}$ \\
\hline $\begin{array}{c}\text { Hyperuricemia } \\
\text { control group }\end{array}$ & $43.94 \pm 3.04^{\mathrm{d}}$ & $1.01 \pm 0.02^{\mathrm{e}}$ & $30.57 \pm 1.58^{\mathrm{d}}$ & $2.41 \pm 0.24^{\mathrm{e}}$ & $16.36 \pm 0.72^{\mathrm{a}}$ \\
\hline $\mathbf{Q S}$ & $87.90 \pm 7.08^{\mathrm{bc}}$ & $2.43 \pm 0.14^{\mathrm{d}}$ & $67.48 \pm 3.34^{\mathrm{c}}$ & $3.28 \pm 0.18^{\mathrm{d}}$ & $8.79 \pm 0.28^{\mathrm{b}}$ \\
\hline $\boldsymbol{N S S}$ & $82.34 \pm 5.14^{\mathrm{c}}$ & $3.21 \pm 0.16^{\mathrm{c}}$ & $83.48 \pm 3.56^{\mathrm{b}}$ & $3.56 \pm 0.24^{\mathrm{c}}$ & $8.60 \pm 0.39^{\mathrm{b}}$ \\
\hline $\mathbf{Q S + N S S}$ & $102.29 \pm 4.03^{\mathrm{a}}$ & $4.15 \pm 0.20^{\mathrm{b}}$ & $90.71 \pm 2.26^{\mathrm{a}}$ & $3.99 \pm 0.09^{\mathrm{b}}$ & $6.63 \pm 0.44^{\mathrm{c}}$ \\
\hline
\end{tabular}

Average values in every column holding unlike superscript $(a, b, c)$ noted significant variation. Means with the same letter are insignificantly different. QS=Quinoa seed NS= Nigella sativa seed 
Table (7): Effect of quinoa and Nigella sativa seeds on HB, PCV, IgM, IgG and interleukin-1 (IL-6) of rats suffering from hyperuricemia

\begin{tabular}{|c|c|c|c|c|c|}
\hline $\begin{array}{l}\text { Parameters } \\
\text { Groups }\end{array}$ & $\begin{array}{l}\mathrm{HB} \\
\mathrm{g} / \mathrm{dl}\end{array}$ & $\begin{array}{c}\mathrm{PCV} \\
\%\end{array}$ & $\operatorname{IgM}(\mathrm{mg} / \mathrm{l})$ & $\operatorname{IgG}(\mathrm{mg} / \mathrm{l})$ & $\begin{array}{l}\text { IL-6(pg/g) } \\
\text { Kidney }\end{array}$ \\
\hline Normal & $13.91 \pm 0.25^{\mathrm{a}}$ & $41.80 \pm 0.88^{\mathrm{a}}$ & $99.29 \pm 5.73^{\mathrm{a}}$ & $198.30 \pm 4.74^{\mathrm{a}}$ & $49.58 \pm 0.83^{c}$ \\
\hline $\begin{array}{l}\text { Hyperuricemia } \\
\text { control group }\end{array}$ & $10.20 \pm 0.48^{d}$ & $30.63 \pm 1.59^{d}$ & $54.91 \pm 3.27^{d}$ & $117.37 \pm 5.48^{\mathrm{e}}$ & $83.96 \pm 5.11^{\mathrm{a}}$ \\
\hline $\mathrm{QS}$ & $12.20 \pm 0.54^{b}$ & $36.66 \pm 1.59^{b}$ & $87.06 \pm 3.86^{\mathrm{c}}$ & $162.90 \pm 5.97^{\mathrm{d}}$ & $64.16 \pm 3.98^{b}$ \\
\hline NSS & $11.51 \pm 0.48^{\mathrm{c}}$ & $34.70 \pm 1.30^{c}$ & $91.18 \pm 2.99^{\mathrm{bc}}$ & $170.18 \pm 5.20^{c}$ & $60.06 \pm 3.44^{b}$ \\
\hline $\mathrm{QS}+N S \mathrm{~S}$ & $11.97 \pm 0.27^{\mathrm{bc}}$ & $36.01 \pm 0.81^{\mathrm{bc}}$ & $95.56 \pm 3.84^{\mathrm{ab}}$ & $190.94 \pm 3.19^{b}$ & $52.99 \pm 1.62^{c}$ \\
\hline
\end{tabular}

Average values in every column holding unlike superscript $(a, b, c)$ noted significant variation. Means with the same letter are insignificantly different $Q S=$ Quinoa seed $\quad$ NS= Nigella sativa seed, 


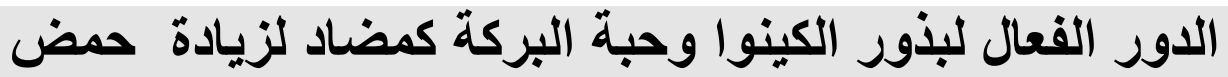 اليوريك في الجرذان}

\section{هالة عزت مصطفى الكواوي 1 و جيهان محمد محمود احمد مرسيץ}

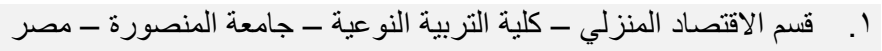

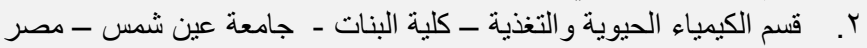

الملخص العربي

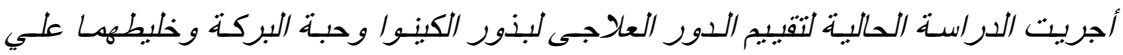

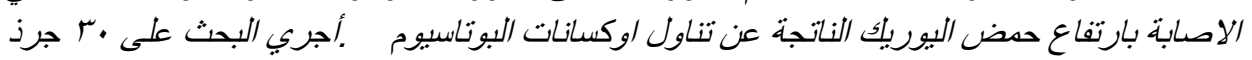

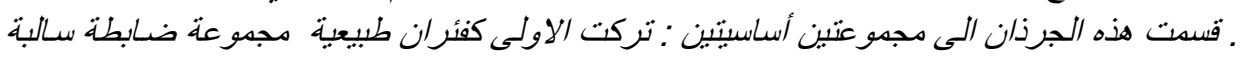

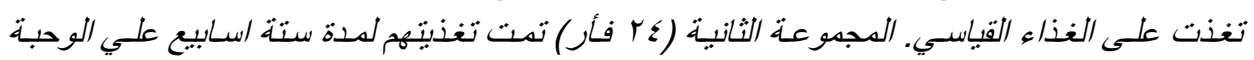

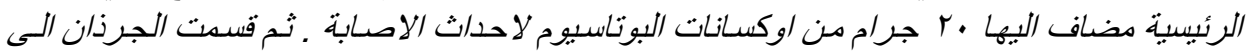

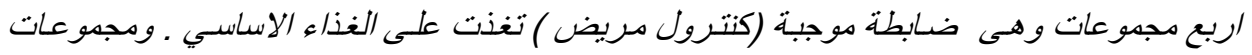

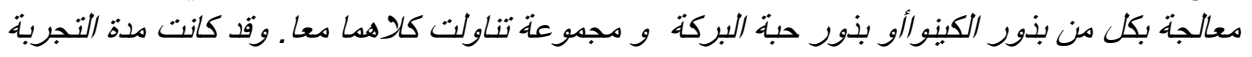

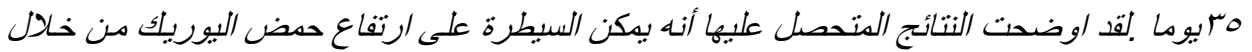

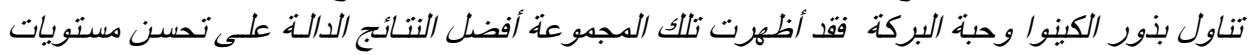

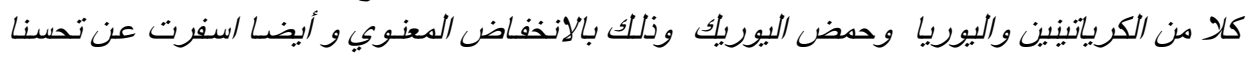

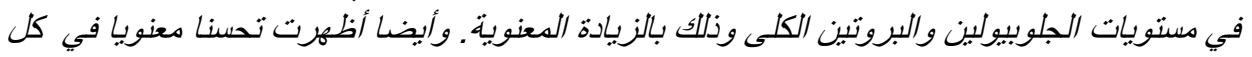

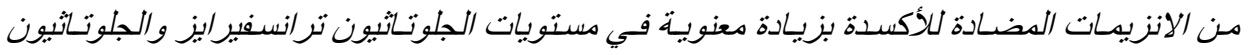

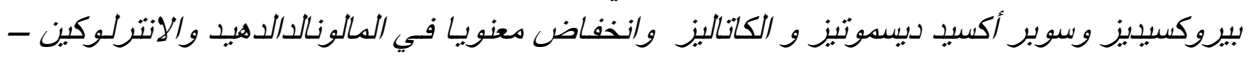

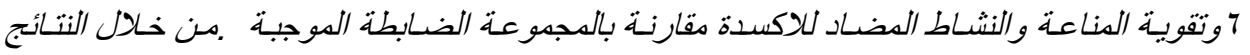

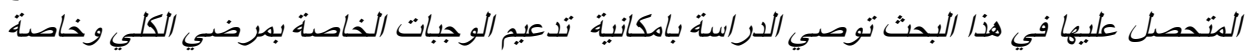

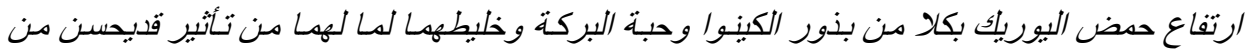

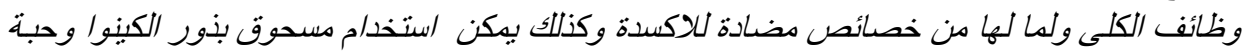

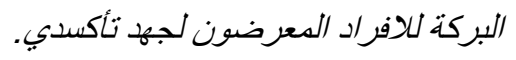
الكلمات المفتاحية: بذور الكبيوا - بذور حبة البركة - ارتفاع حصض اليوريك 